\title{
REVIEW ARTICLE \\ PREGNANCY DIAGNOSIS IN SHEEP: REVIEW OF THE MOST PRACTICAL METHODS
}

\author{
A. KAREN ${ }^{1}$, P. KOVÁCS ${ }^{2}$, J. F. BECKERS ${ }^{3}$, O. SZENCI ${ }^{1}$ \\ ${ }^{1}$ Department of Obstetrics and Reproduction, Faculty of Veterinary Science, Szent István University, Hungary; \\ ${ }^{2}$ Awassi Rt., Bakonszeg, Hungary \\ ${ }^{3}$ Department of Physiology of Reproduction, Faculty of Veterinary Medicine, University of Liege, Belgium
}

Received September 19, 2000

Accepted May 28, 2001

Abstract

Karen A., P. Kovács, J.F. Beckers, O. Szenci: Pregnancy Diagnosis in Sheep: Review of the Most Practical Methods. Acta Vet. Brno 2001, 70: 115-126.

Various practical methods have been used for pregnancy diagnosis in sheep. Both pregnancy and fetal numbers are accurately diagnosed by using radiography after day 70 of gestation. Rectal abdominal technique detects pregnancy with an accuracy of 66 to $100 \%$ from d 49 to 109 of gestation, however, it has a low (17 to 57\%) accuracy for determining multiple fetuses. Progesterone assays have a high sensitivity (88\% to $100 \%)$ and a low specificity $(60 \%$ to $72 \%)$ at $\mathrm{d} 16$ to 18 . Estrone sulphate assay accurately detects pregnant ewe at $\mathrm{d} 30$ to 35 . Ovine pregnancy specific protein B (PSPB) assay accurately $(100 \%)$ detects pregnancy from d 26 after breeding onwards. The accuracy of progesterone, estrone sulphate and oPSPB assays for determining fetal numbers is relatively low. A-mode and Doppler ultrasonic techniques accurately detect pregnancy during the second half of gestation. Fetal numbers cannot be determined by A-mode ultrasound, while the Doppler technique needs experience to achieve high accuracy. Transrectal B-mode, real time ultrasonography identifies the embryonic vesicles as early as d 12.8 after mating, but the sensitivity of the technique for pregnancy is very low (12\%) earlier than $25 \mathrm{~d}$ after mating. Transabdominal B-mode ultrasonography achieved high accuracy for pregnancy diagnosis ( $94 \%$ to $100 \%$ ) and the determination of fetal numbers ( $92 \%$ to $99 \%$ ) on d 29 to 106 of gestation. Realtime, B-mode ultrasonography appears to be the most practical and accurate method for diagnosing pregnancy and determining fetal numbers in sheep.

Pregnancy diagnosis, ewe, radiography, rectal-abdominal palpation, hormonal assays, pregnancy proteins, ultrasonography

Early detection of pregnancy is of considerable economic value to sheep industry. Nonpregnant ewes could be sold, reducing feed expenses, while non-pregnant lambs could be marketed at higher price than they would bring as mature ewes (Gearhart et al. 1988). Separation of the sheep herd into pregnant and non-pregnant ewes might reduce reproductive and production losses in form of abortions, stillbirths and production of weak lambs (Wani et al. 1998).

Predictions of the number of fetuses would allow appropriate nutritional management of the ewes in late gestation that will prevent pregnancy toxemia (Ford 1983), minimize prelambing feeding costs, optimize birth weight, weaning weight and survivability of lambs and reduce the incidence of dystocia (Gearhart et al. 1988). In addition, the accurate information on the stage of gestation would be useful to dry off lactating females at adequate period and to monitor the females near term (Doize et al. 1997).

Methods of pregnancy diagnosis

Various methods have been used to diagnose pregnancy in sheep. These methods can be classified as less practical such as the management method (non-return to estrus), abdominal 
palpation and ballotment, palpation of the caudal uterine artery, laparotomy, peritoneoscopy and rosette inhibition test reviewed by Ish w ar (1995), and the most practical methods such as radiography, rectal abdominal palpation, hormonal assays, pregnancy protein assays and ultrasonography. In the present review, only the most practical methods are discussed.

\section{Radiography}

Ford et al. (1963) examined 322 ewes by radiography and reported 100\% and 90\% accuracy for diagnosing pregnancy and determination of the fetal number, respectively, after 70 days of gestation. Grace et al. (1989) reported 94 to $100 \%$ accuracy of radiography for determining fetal numbers in 13 sheep flocks. Besides the accuracy, the technique is quick; 400 to 600 ewes can be tested per day under farm conditions. The cost of the equipment and the potential health hazard to the operator may limit its use in the field (West 1986).

\section{Rectal abdominal palpation}

Pregnancy diagnosis in sheep was determined by gentle insertion of a lubricated glass rod ( $1.5 \mathrm{~cm}$ in diameter and $50 \mathrm{~cm}$ long) into the rectum of ewe lying on its back. The free hand was placed on the posterior abdomen while the rod was manipulated with the other hand (Hulet 1972). At the early stage of pregnancy, the sensitivity of the technique for diagnosing pregnancy was low but it increased with progressing of the pregnancy reaching the highest accuracy (100 \%) at Days 85 to 109 after mating (Hulet 1972; Chauhan et al. 1991; see Table 1). In contrast, others (Tyrrell and Plant 1979; Trapp and Slyter 1983) reported a lower sensitivity and specificity at d 60 to 96 after mating (Table 1). Although this technique is simple, cheap and quick (150 ewes can be examined per hour), it had a low accuracy in diagnosing multiple fetuses (Table 2) and was more hazardous with respect to rectal injury (Tyrrell and Plant 1979) and abortion (Turner and Hindson 1975; Ishwar 1995).

Table 1

Sensitivity (Se), specificity $(\mathrm{Sp})$, and predictive (+PV, $-\mathrm{PV})$ values of rectal abdominal technique for pregnancy diagnosis in sheep

\begin{tabular}{|c|c|c|c|c|c|c|c|c|c|c|}
\hline $\begin{array}{c}\text { No. of } \\
\text { animals }\end{array}$ & $\begin{array}{c}\text { Days of } \\
\text { exam. }\end{array}$ & $\mathrm{a}$ & $\mathrm{b}$ & $\mathrm{c}$ & $\mathrm{d}$ & $\begin{array}{c}\text { Se } \\
\%\end{array}$ & $\begin{array}{c}\text { Sp } \\
\%\end{array}$ & $\begin{array}{c}+\mathrm{PV} \\
\%\end{array}$ & $\begin{array}{c}-\mathrm{PV} \\
\%\end{array}$ & Authors \\
\hline 79 & 85 to 109 & 61 & 0 & 18 & 0 & 100 & 100 & 100 & 100 & Hulet 1972 \\
\hline 432 & 21 to 55 & & & & & 59 & & & & Tyrrell \& Plant 1979 \\
\hline 99 & 49 to 83 & & & & & 73 & & & & Tyrrell \& Plant 1979 \\
\hline 498 & 60 to 96 & 173 & 97 & 139 & 89 & 66 & 59 & 62 & 61 & Trapp \& Slyter 1983 \\
\hline 14 & & 10 & 2 & 2 & 0 & 100 & 50 & 82 & 100 & Chauhan et al.1991 \\
\hline
\end{tabular}

a, correct positive (pregnant); b, false positive (non-pregnant); c, correct negative (non-pregnant); $\mathrm{d}$, false negative (pregnant)

Table 2

Sensitivity (Se), specificity (Sp), and predictive (+PV, -PV) values of rectal abdominal technique in determination of fetal numbers

\begin{tabular}{|c|c|c|c|c|c|c|c|c|c|c|}
\hline $\begin{array}{c}\text { No. of } \\
\text { animals }\end{array}$ & $\begin{array}{c}\text { Days of } \\
\text { exam. }\end{array}$ & $\mathrm{a}$ & $\mathrm{b}$ & $\mathrm{c}$ & $\mathrm{d}$ & $\begin{array}{c}\mathrm{Se} \\
\%\end{array}$ & $\begin{array}{c}\text { Sp } \\
\%\end{array}$ & $\begin{array}{c}+\mathrm{PV} \\
\%\end{array}$ & $\begin{array}{c}-\mathrm{PV} \\
\%\end{array}$ & Authors \\
\hline 41 & 90 to 105 & 4 & 1 & 33 & 3 & 57 & 97 & 80 & 92 & Hulet (1973) \\
\hline 12 & & 1 & 1 & 5 & 5 & 17 & 83 & 50 & 50 & Chauhan et al. (1991) \\
\hline
\end{tabular}

a, correct positive (multiple); $b$, false positive (single); c, correct negative (single); $d$, false negative (multiple) 
The technique of bimanual palpation of small ruminants was developed by Kutty and Sudarsanan (1996). This method includes digital palpation per rectum combined with abdominal manipulation. By using this technique pregnant ewes $(n=9)$ were accurately diagnosed based on enlarged cervix, prepubic position of the uterus, palpation of placentomes and/or fetal parts, asymmetry and/or marked distension of uterine horns and inability to palpate the ovaries (Kutty 1999).

\section{Hormonal assays}

\subsection{Assessment of progesterone}

Measurement of blood progesterone concentration is a reliable indicator of the functional corpus luteum. Concentration of plasma progesterone samples was determined in ewes on Day 18 post-breeding by using enzyme immunoassay (EIA) and radioimmunoassay (RIA). The accuracy of both type of assays for detecting pregnancy was high, while it was low for diagnosing non-pregnancy (Amezcua-Moreno 1988; Susmel and Piasentier 1992; Gvozdic and Ivkov 1994; see Table 3). On the other hand, 100\% accuracy for detecting non-pregnant ewes was achieved by using EIA at Day 16 (McPhee and Tiberghien 1987) and Day 21 after mating (Zarkawi 1997) or by using RIA at Days 17 to 18 (Zarkawi et al. 1999; see Table 3). Early embryonic death, uterine and/or ovarian pathology may be the source of the false positive cases. At Days $100 \pm 9$ after breeding, the accuracy of progesterone assay for pregnancy diagnosis was $98 \%$ in ewe lambs and $99 \%$ in mature ewes (Schneider and Hallford 1996).

Table 3

Sensitivity (Se), specificity (Sp), and predictive (+PV, -PV) values of progesterone assay for diagnosing pregnancy in sheep

\begin{tabular}{|c|c|c|c|c|c|c|c|c|c|c|}
\hline $\begin{array}{c}\text { Days of } \\
\text { exam. }\end{array}$ & $\begin{array}{c}\text { No. of } \\
\text { animals }\end{array}$ & $\mathrm{a}$ & $\mathrm{b}$ & $\mathrm{c}$ & $\mathrm{d}$ & $\begin{array}{c}\text { Se } \\
\%\end{array}$ & $\begin{array}{c}\text { Sp } \\
\%\end{array}$ & $\begin{array}{c}+\mathrm{PV} \\
\%\end{array}$ & $\begin{array}{c}-\mathrm{PV} \\
\%\end{array}$ & Authors \\
\hline 16 to 17 & 130 & 106 & 0 & 24 & 0 & 100 & 100 & 100 & 100 & McPhee \& Tiberghien (1987) \\
\hline 18 & 170 & & & & & 91 & 64 & & & Amezcua-Moreno (1988) \\
\hline 18 & 112 & 80 & 9 & 23 & 0 & 100 & 72 & 90 & 100 & Susmel \& Piasentier (1992) \\
\hline 16 to 18 & 22 & 15 & 2 & 3 & 2 & 88 & 60 & 88 & 60 & Gvozdic \& Ivkov (1994) \\
\hline 21 & 16 & 16 & 0 & 0 & 0 & 100 & & 100 & & Zarkawi (1997) \\
\hline 17 to 18 & 24 & 24 & 0 & 0 & 0 & 100 & & 100 & & Zarkawi et al. (1999) \\
\hline
\end{tabular}

$\mathrm{a}$, correct positive (pregnant); b, false positive (non-pregnant); c, correct negative (non-pregnant); $\mathrm{d}$, false negative (pregnant)

EIA test for the measurement of faecal immunoreactive Pregnendiol-3-Glucuronide (iPd G), a progesterone metabolite, was a useful tool for diagnosing pregnancy in Bighorn sheep with $100 \%$ accuracy from about Day 60 of pregnancy until a few days before parturition. (Borjesson et al. 1996).

Concerning the estimation of the fetal number, serum progesterone concentration was significantly higher in ewes carrying two and three fetuses than those carrying one fetus (19.2 and $29.9 \mathrm{ng} / \mathrm{ml}$, vs $9.2 \mathrm{ng} / \mathrm{ml}$, respectively) (Chauh an and Waziri 1991). There was a positive relationship between the number of fetuses and the mean plasma progesterone concentrations $(P<0.001)$ after the second half of pregnancy (Kalkan et al. 1996). The number of fetuses was estimated with $88 \%$ accuracy in ewe lambs and with $74 \%$ accuracy in mature ewes on Days $100 \pm 9$ after breeding (Schneider and Hallford 1996). In contrast, others reported a much lower accuracy (25\%) for ewes carrying multiple fetuses 
(Chauhan et al. 1991; Sandabe et al. 1994).

Regarding the fetal sex, the plasma progesterone concentrations of ewes giving birth to male and female lambs were not significantly different (Kalkan et al. 1996).

\section{2-Assessment of estrone sulphate}

The presence of a viable feto-placental unit is accompanied by an increase in estrone sulphate concentrations in the peripheral plasma of ewes. Estrone sulphate was detectable around Day 70 of gestation with value ranging between 0.1 to $0.7 \mathrm{ng} / \mathrm{ml}$, then its level increased steadily till 2 days before parturition when an upsurge was seen $(15-50 \mathrm{ng} / \mathrm{ml})$ (Tsang 1978). On Day 85 of gestation, there was a significant difference in the level of estrone sulphate between pregnant and non-pregnant ewes. However, due to considerable variation of the hormone levels between individuals, the accuracy for detection of non-pregnancy was only $44 \%$ whilst for detection of pregnancy it was $87.9 \%$ using the cut-off value of $0.1 \mathrm{ng} / \mathrm{ml}$ (Worsfold et al. 1986). On the contrary, Illera et al. (2000) reported that the EIA test for the measurements of serum estrone sulphate concentrations gave an optimal accuracy for pregnancy diagnosis between Days 30 to 35 of gestation.

Regarding the fetal number, the concentration of serum estrone sulphate was significantly higher in ewes carrying multiple than those carrying single fetus from Days 80 to 124 of gestation (Illera et al. 2000). However, the determination of estrone sulphate concentrations in ovine blood might not be reliable for prediction of fetal numbers due to the high variation between individuals (Worsfold et al. 1986).

3.3. Ovine chorionic somatommamotrophin (oCS) or ovine placental lactogen (oPL)

Ovine placental lactogen (oPL) was studied and purified by Chan et al. (1978). RIA assay of oPL achieved $97 \%$ and $100 \%$ accuracy for diagnosing pregnant and non-pregnant ewes at Day 64 of gestation, respectively (Roberts on et al. 1980).

4. Assessment of pregnancy proteins

4.1. Pregnancy-specific protein B (PSPB)

Pregnancy-specific protein B (PSPB) first detected in the bovine placenta (Butler et al. 1982), is secreted by binucleate cells of fetal trophoectoderm (Eckblad et al.1985). The physiological role of PSPB during pregnancy might be the maintenance of corpus luteum by stimulating prostaglandin E2 production (Vecchio et al. 1995).

Although the RIA test for the measurements of bovine PSPB accurately detects pregnancy $(100 \%)$ and non-pregnancy (83\%) in sheep from Days 26 to 106 of gestation (Table 4), ovine PSPB concentration cannot be measured quantitatively because ovine antigen cross-reacts only incompletely with antibodies to bPSPB (Ruder et al. 1988).

Table 4

Sensitivity (Se), specificity (Sp) and predictive (+PV, -PV) values of oPSPB assay for pregnancy diagnosis in sheep

\begin{tabular}{|c|c|c|c|c|c|c|c|c|c|c|}
\hline $\begin{array}{c}\text { Days of } \\
\text { exam. }\end{array}$ & $\begin{array}{c}\text { No. of } \\
\text { animals }\end{array}$ & $\mathrm{a}$ & $\mathrm{b}$ & $\mathrm{c}$ & $\mathrm{d}$ & $\begin{array}{c}\mathrm{Se} \\
\%\end{array}$ & $\begin{array}{c}\mathrm{Sp} \\
\%\end{array}$ & $\begin{array}{c}+\mathrm{PV} \\
\%\end{array}$ & $\begin{array}{c}-\mathrm{PV} \\
\%\end{array}$ & Authors \\
\hline $26-96$ & 33 & 30 & 2 & 1 & 0 & 100 & 33 & 94 & 100 & Ruder et al. (1988) \\
\hline $35-106$ & 180 & 159 & 2 & 19 & 0 & 100 & 90 & 99 & 100 & Ruder et al. (1988) \\
\hline Total & 213 & 189 & 4 & 20 & 0 & 100 & 83 & 97 & 100 & \\
\hline
\end{tabular}

a, correct positive (pregnant); b, false positive (non-pregnant); c, correct negative (non-pregnant); $\mathrm{d}$, false negative (pregnant) 
Willard et al. (1987) developed a quantitative RIA test for the measurements of ovine pregnancy specific protein B (oPSPB). oPSPB became detectable at 19.7 \pm 0.1 (Mean \pm SE) (Willard et al. 1987; 1995) and $21.7 \pm 0.6$ days postmating (Wallace et al. 1997). Then, it increased steadily until Day 30 when it was $10.8 \pm 0.4 \mathrm{ng} / \mathrm{ml}$. The concentration remained stable within a period of $20 \mathrm{~d}$ prepartum (Willard et al. 1995). After lambing, the concentration dropped rapidly and it was last detectable at $12.8 \pm 2.3 \mathrm{~d}$ (Willard et al. 1995) and $3 \pm 0.1$ weeks postpartum (Willard et al. 1987).

By using the RIA test for the measurements of oPSPB, the accuracy for detecting ewes carrying single and twin lambs was $71 \%$ and $81 \%$, respectively, from Days 60 to 120 of gestation (Willard et al. 1995). At the same time, oPSPB concentrations were not influenced by the sex of the fetus (Wallace et al. 1997).

PSPB might be a useful marker of placental development and function and provide a reliable indicator of fetal distress and adverse pregnancy outcome. Between Days 50 and 100 of gestation, PSPB concentrations were positively correlated with placental weight at term. In addition, the mass of the fetus in ewes that aborted during late pregnancy was highly correlated with PSPB concentrations up to Day 120 of gestation (W allace et al. 1997).

\subsection{Ovine pregnancy-associated glycoproteins (oPAGs)}

Ovine pregnancy-associated glycoproteins (oPAGs) are synthesized by binucleate cells of trophoblast, and belong to aspartic proteinase family (Xie et al. 1991) and most of them are without enzyme activity (Xie et al. 1997). They have molecular weights between 43 to $67 \mathrm{kDa}$ (Zoli et al. 1995; Xie et al. 1997).

The concentration of oPAG in Churra and Merino ewes was detectable in some (20/30) ewes at Week 3 and in all ewes on Week 4 after mating (Ranilla et al. 1994). The concentration of oPAG increased slowly from Weeks 3 to 9 of gestation. Thereafter, plasmatic profiles of oPAG varied among sheep breeds from Week 9 till Week17, however, oPAG concentrations increased in all studied breeds from Week 17 till lambing. After lambing, the oPAG levels decreased rapidly reaching the basal value at fourth week postpartum (Ranilla et al. 1994 and 1997; Gajewski et al. 1999).

The concentration of oPAG might be influenced by the fetal numbers and the sex of the fetus. Ewes carrying two fetuses had higher mean oPAG concentrations than those carrying a single fetus from Week 12 of gestation to lambing. This difference was only significant at Week 21 (Ranilla et al. 1997). Also, ewes carrying male fetuses had oPAG concentrations higher than those carrying female fetuses at Weeks 19, 20 and 21 of gestation (Ranilla et al. 1994).

Although bPAG and cPAG have been successfully used for detecting pregnancy in cattle (Zoli et al. 1992; Szenci et al. 1998) and goats, respectively, (Folch et al. 1993, Gonzalez et al. 1999), there is no data evaluating the accuracy of oPAG assays for diagnosing pregnancy in sheep.

\section{Ultrasonography}

In the past 20 years, three types of ultrasonographic systems were used for pregnancy diagnosis in small ruminants.

\subsection{A-mode ultrasound (Amplitude-depth or echo-pulse)}

In this system, the transducer containing one crystal emits ultrasound waves which penetrate the tissues under the skin and reflect when meet a high acoustic impedance interfaces (pregnant uterus or fluid-filled structures). The transducer receives the reflected echoes and converts them into peaks on oscilloscope with horizontal scale representing the depth of the reflecting structure or into audible signal.

Meredith and Madani (1980) used the reflection of ultrasound at depth $9 \mathrm{~cm}$ or greater as a positive sign of pregnancy in ewe and reported $96 \%$ sensitivity and $87.5 \%$ specificity 
in the period from 61 to 151 days after mating. However, by the same approach, lower sensitivity $(86.7 \%)$ and specificity $(69 \%)$ were reported in the ewe lambs at Days 73 to 103 postmating (Madel 1983). By using echo-pulse detectors, the accuracy for detecting pregnant ewes averaged 91\% from Days 69 to 112 of gestation (Trapp and Slyter 1983). However, Watt et al. (1984) reported $97 \%$ accuracy for diagnosing pregnancy from Day 51 of gestation to lambing. A-mode ultrasound is a quick, convenient and simple technique, but it cannot predict the fetal number and the viability of the fetus.

\subsection{Doppler ultrasound}

Doppler devices utilize the Doppler shift principle to detect the fetal heart beats and flow of blood in uterine and fetal vessels. Lindahl (1971) reported that the intrarectal Doppler technique could be used for diagnosing pregnancy at the beginning of the second third with an accuracy of $90 \%$ or better. According to the work reported by Deas (1977) the accuracy of intrarectal Doppler transducer for diagnosing pregnancy and non-pregnancy was $82 \%$ and $91 \%$, respectively, from Days 41 to 60 of gestation. After Day 71, the accuracy for diagnosing pregnancy and non-pregnancy ranged between $85 \%$ and $94 \%$, respectively (Watt et al. 1984). In contrast, Trapp and Slyter (1983) reported $68 \%$ and $84 \%$ accuracy for diagnosing pregnancy and non-pregnancy from Days 60 to 96 of gestation. The use of an external Doppler transducer gave almost $100 \%$ accuracy for diagnosing pregnancy after Day 111 of gestation (W att et al. 1984).

Concerning the predictions of fetal numbers, the external Doppler technique, when used by skilled operator gave $83 \%$ and $93 \%$ accuracy for diagnosing single and multiple fetuses at Days 80 to 95 of gestation, respectively (Fukui et al. 1986). However, Fukui et al. (1984) reported $74 \%$ and $89 \%$ accuracy for ewes carrying single and multiples, respectively from Days 60 to 120 of gestation. Doppler devices have not been used successfully for estimating ovine gestational age (Russel and Goddard 1995).

\subsection{Real-time, B-mode ultrasonography}

Real-time B-mode ultrasonic scanning of the uterus in sheep appears to offer an accurate, rapid, safe and practical means for diagnosing pregnancy, determination of fetal numbers and estimation of gestational age.

\subsubsection{Diagnosis of pregnancy}

By using transrectal ultrasonography $(7.5 \mathrm{MHz})$, embryonic vesicle of the pregnant Manchega dairy ewe was identified at Day 12.8 after mating, while the first visualization of

Table 5

Sensitivity (Se), specificity (Sp) and predictive (+PV, - PV) values of using transrectal (5 MHz and 7.5 MHz) ultrasonography for pregnancy diagnosis in sheep

\begin{tabular}{|c|c|c|c|c|c|c|c|c|c|c|c|}
\hline $\begin{array}{c}\text { Days of } \\
\text { exam. }\end{array}$ & MHz & $\begin{array}{c}\text { No. of } \\
\text { animal }\end{array}$ & $\mathrm{a}$ & $\mathrm{b}$ & $\mathrm{c}$ & $\mathrm{d}$ & $\begin{array}{c}\text { Se } \\
\%\end{array}$ & $\begin{array}{c}\text { Sp } \\
\%\end{array}$ & $\begin{array}{c}+\mathrm{PV} \\
\%\end{array}$ & $\begin{array}{c}\text {-PV } \\
\%\end{array}$ & Authors \\
\hline 25 to 50 & 5 & 64 & 33 & 1 & 25 & 5 & 87 & 96 & 97 & 83 & Buckrell et al. (1986) \\
\hline 0 to 25 & 5 & 26 & & & & & 12 & 100 & & & Gearthart et al. (1988) \\
\hline 26 to 50 & 5 & 26 & & & & & 65 & 100 & & & Gearthart et al. (1988) \\
\hline 24 to 26 & 5 & 91 & 17 & 3 & 62 & 9 & 65 & 95 & 85 & 87 & Garcia et al. (1993) \\
\hline 32 to 34 & 5 & 91 & 22 & 1 & 64 & 4 & 85 & 98 & 96 & 94 & Garcia et al. (1993) \\
\hline 0 to 60 & 7.5 & 117 & 94 & 8 & 13 & 2 & 98 & 62 & 92 & 87 & Schrick \& Inskeep (1993) \\
\hline
\end{tabular}

a, correct positive (pregnant); b, false positive (non-pregnant); c, correct negative (non-pregnant); $\mathrm{d}$, false negative (pregnant) 
the embryo was at Day 19 (Gonzalez et al. 1998) or Day 20 (Schrick and Inskeep 1993). By using $5 \mathrm{MHz}$ transrectal probe, the first signs of pregnancy in form of circular and elongated anaechoic images located in utero cranial to bladder were observed in ewe on Days 17 to 19 (Garcia et al. 1993; Doize et al. 1997), while embryo could be detected on Day 25 after mating (Buckrell et al. 1986).

The specificity of $7.5 \mathrm{MHz}$ transrectal ultrasonography for diagnosing non-pregnancy was low during the first two months of gestation (Schrick and Inskeep 1993; Table 5). The false positive diagnoses were attributed to embryonic or fetal death. The sensitivity of $5 \mathrm{MHz}$ transrectal ultrasonography for detecting pregnant ewes was very low (12\%) at less than Day 25 of gestation (Gearhart et al. 1988). Thereafter, the sensitivity increased with progressing the pregnancy and ranged between $65 \%$ and $87 \%$ at Days 25 to 50, depending on the breed, age and parity of the ewes and the technique of the examination (B uckrell et al. 1986; Gearhart et al. 1988; Garcia et al. 1993; Table 5).

By using transabdominal approach, pregnancy was first verified at Day 25 (Gearhart et al. 1988) or Day 30 after breeding (Bretzlaff et al. 1993). The sensitivity and specificity of the technique were high after Day 29 (Taverne et al. 1985) reaching approximately 100\% from Days 46 to 106 of gestation (White et al. 1984; Fowler and Wilkins 1984; Davey 1986; Gearhart et al. 1988). However, Logue et al. (1987) reported a lower specificity on Days less than 40 to100 after mating (Table 6).

Table 6

Sensitivity (Se), specificity (Sp) and predictive (+PV, - PV) values of using transabdominal $(3,3.5$ and $5 \mathrm{MHz})$ ultrasonography for pregnancy diagnosis in sheep

\begin{tabular}{|c|c|c|c|c|c|c|c|c|c|c|c|}
\hline $\begin{array}{c}\text { Days of } \\
\text { exam. }\end{array}$ & MHz & $\begin{array}{c}\text { No. of } \\
\text { animal }\end{array}$ & $\mathrm{a}$ & $\mathrm{b}$ & $\mathrm{c}$ & $\mathrm{d}$ & $\begin{array}{c}\text { Se } \\
\%\end{array}$ & $\begin{array}{c}\text { Sp } \\
\%\end{array}$ & $\begin{array}{c}+\mathrm{PV} \\
\%\end{array}$ & $\begin{array}{c}-\mathrm{PV} \\
\%\end{array}$ & Authors \\
\hline 46 to 106 & 3.5 & 5530 & 5006 & 1 & 491 & 32 & 99 & 100 & 100 & 94 & Fowler \& Wilkins (1984) \\
\hline 46 to 93 & 3.5 & 554 & 520 & 0 & 34 & 0 & 100 & 100 & 100 & 100 & White et al. (1984) \\
\hline 29 to 89 & 3 & 724 & 593 & 3 & 123 & 5 & 99 & 98 & 99 & 96 & Taverne et al. (1985) \\
\hline 50 to 100 & 3.5 & 516 & 473 & 0 & 37 & 6 & 99 & 100 & 100 & 88 & Davey (1986) \\
\hline$<40$ to $>100$ & & 2499 & 2331 & 21 & 141 & 6 & 100 & 87 & 99 & 96 & Logue et al. (1987) \\
\hline 51 to 75 & 5 & 26 & 24 & 0 & 2 & 0 & 100 & 100 & 100 & 100 & Gearhart et al. (1988) \\
\hline
\end{tabular}

a, correct positive (pregnant); b, false positive (non-pregnant); c, correct negative (non-pregnant); $\mathrm{d}$, false negative (pregnant)

Table 7

Sensitivity (Se), Specificity (Sp) and Predictive (+PV, -P V) values of using transrectal (TR) and transabdominal (TA) ultrasonography for determination of fetal numbers in sheep

\begin{tabular}{|c|c|c|c|c|c|c|c|c|c|c|c|}
\hline $\begin{array}{c}\text { Days of } \\
\text { exam. }\end{array}$ & $\begin{array}{c}\text { Method } \\
\text { of } \\
\text { exam. }\end{array}$ & $\begin{array}{c}\text { No. of } \\
\text { animals }\end{array}$ & a & b & c & d & $\begin{array}{c}\text { Se } \\
\%\end{array}$ & $\begin{array}{c}\text { Sp } \\
\%\end{array}$ & $\begin{array}{c}+ \text { PV } \\
\%\end{array}$ & $\begin{array}{c}- \text { PV } \\
\%\end{array}$ & Authors \\
\hline 46 to 106 & TA & 5039 & 1328 & & 3577 & & 94 & 99 & 99 & 98 & Fowler \&Wilkins (1984) \\
\hline 46 to 93 & TA & 520 & 327 & 1 & 190 & 2 & 99 & 99 & 100 & 99 & White et al. (1984) \\
\hline 45 to 77 & TA & 210 & 142 & 5 & 53 & 10 & 93 & 91 & 97 & 84 & Taverne et al. (1985) \\
\hline 50 to 100 & TA & 479 & 118 & 0 & 349 & 12 & 91 & 100 & 100 & 97 & Davey (1986) \\
\hline$<40$ to $>100$ & TA & 2348 & 1216 & & 1006 & & 96 & 94 & 95 & 94 & Logue et al. (1987) \\
\hline 26 to 50 & TR & 24 & & & & & 5 & 80 & & & Gearhart et al. (1988) \\
\hline 51 to 75 & TA & 24 & & & & & 97 & 100 & & & Gearhart et al. (1988) \\
\hline
\end{tabular}

a, correct positive (multiple); $b$, false positive (single); c, correct negative (single); $d$, false negative (multiple) 
5.3.2. Determination of the fetal number

By using transrectal ultrasonography (7.5 MHz), single and multiple pregnancies in sheep were accurately (15 of 17 ewes) detected on Day 25 (Schrick and Inskeep 1993). However, the accuracy of a $5 \mathrm{MHz}$ transrectal ultrasonography for detecting ewes carrying two fetuses or more was disappointing (Gearhart et al. 1988; Table 7). By using transabdominal ultrasonography, the accuracy of experienced operator for determination both single- and multiple-bearing ewes was $99 \%$ from Days 46 to 93 of gestation (White et al. 1984). A similar accuracy for ewes carrying single fetus was reported by Fowler and Wilkins (1984), Davey (1986) and Gearhart et al. (1988), however, a lesser accuracy for ewes carrying multiples was reported by others (Table 7).

\subsubsection{Estimation of gestational age}

When the date of mating is unknown, monitoring fetal development allows estimation of gestational age.

A-Embryonic vesicle

Gonzalez et al. (1998) measured the ovine embryonic vesicle from Days 12 to 29 of gestation by using $7.5 \mathrm{MHz}$ transrectal ultrasonography and found a close correlation $(\mathrm{r}=$ $0.76)$ with the gestational age.

\section{B-Crown-Rump length}

By using transrectal ultrasonography (7.5 MHz), Schrick and Inskeep (1993) measured the crown-rump length of the ovine fetus from Days 20 to 40 of gestation and described the relationship between the crown-rump length (x) and the gestational age (y) by the following equation, $\mathrm{Y}=14.05+1.16 \mathrm{x}-0.012 \mathrm{x}^{2}$. By using the same approach, Gonzalez et al. (1998) reported a high $(r=0.94)$ correlation between the crown-rump length and the gestational age from Days 19 to 48 of gestation.

\section{C-Fetal head diameters}

Fetal head diameters including the biparietal diameter, the occipito-nasal length and the diameter of the orbit were used to predict the stage of gestation in sheep.

Regarding to the biparietal diameter (BPD), Gonzalez et al. (1998) used the transrectal ultrasonography to measure the BPD of Manchega sheep from Days 32 to 90 and found a high correlation $(r=0.96)$ between the measured diameters and the gestational age. Similar correlation was found by using transabdominal approach in Suffolk and Finn sheep from Days 40 to 95 (Haibel and Perkins 1989), in Booroola x South Australian Merino sheep from Days 49 to 109 (Sergeev et al. 1990) and in Swedish peltsheep from 10 weeks before lambing to birth (Aiumlamai et al. 1992).

Kelly and Newnham (1989) found the occipito-nasal length to be more accurate than BPD, showing a linear increase till Day 80. However, Sergeev et al. (1990) reported that the occipito-nasal length was more difficult to be measured than BPD and had the same accuracy for predicting fetal age. Gonzalez et al. (1998) found a high correlation $(r=0.95)$ between the fetal occipito-nasal length and the gestational age from Days 38 to 91 of gestation.

Regarding the diameter of the fetal orbit, Gonzalez et al. (1998) reported that the ovine fetal orbit increased in diameter from $2 \mathrm{~mm}$ at Day 36 to $17 \mathrm{~mm}$ at Day 90 of gestation and it gave a high correlation $(\mathrm{r}=0.92)$ with the fetal age.

\section{D-Thoracic diameter}

Ultrasonographic measurements of the ovine fetal thoracic diameter showed high 
correlation with the fetal age from Days 49 to 109 (Sergeev et al. 1990) and from Days 23 to 90 of gestation (Gonzalez et al. 1998).

\section{E-Fetal heart rate}

By using $7.5 \mathrm{MHz}$ transrectal ultrasonography, the rhythmic pulsations within the ovine embryonic vesicle were first detected on Day 18 or 19 after mating (Schrick and Inskeep 1993), while by using $5 \mathrm{MHz}$ transrectal ultrasonography, they were first observed from Days 21-23 after mating (Garcia et al. 1993). Aiumlamai et al. (1992) measured the ovine fetal heart rate during the second half of pregnancy by using transabdominal ultrasonography and reported that the fetal heart rate reached a plateau at 7 weeks before lambing $(167 \pm 1.5 \mathrm{bpm})$ then decreased at 3 weeks before lambing $(139.0 \pm 15.7 \mathrm{bpm})$ and reached $117.0 \pm 9.2 \mathrm{bpm}$ at birth. In addition, a significant correlation was found between fetal heart rate and gestational age.

\section{F-Placentome size}

Placentomes could be detected by transrectal ultrasonography $(5 \mathrm{MHz})$ on Day 30 (B uckrell et al. 1986) and on Day 32 of gestation (Doize et al. 1997). At this period the placentomes appeared as echogenic areas on the surface of endometrium. On Day 42, the ovine placentomes presented cup-shaped forms and reached the maximum size by Day 74 (Doize et al. 1997). There was a poor correlation between placentome size and ovine gestational age due to great variation in the size of placentome in the same observations (Doize et al. 1997; Gonzalez et al. 1998). In contrast, Kelly et al. (1987) found a significant quadratic relationship between ultrasonographic cotyledon diameter and square root transformation of day of pregnancy.

\section{G-Other fetal structures}

There was a high correlation $(\mathrm{r}=0.96)$ between the width of three ovine fetal coccygeal vertebrae and gestational age. At the same time, somewhat lower correlation was found for umbilical cord diameter $(\mathrm{r}=0.72)$ and fetal femur length $(\mathrm{r}=0.78)$ (Gonzalez et al. 1998).

\subsection{Determination of fetal sex}

Depending on the location of the genital tubercle of the ovine fetus, the accuracy of the transrectal ultrasonography $(5 \mathrm{MHz})$ for detecting male and female fetuses was $100 \%$ and $76 \%$, respectively from Days 60 to 69 of gestation (Coubrough and Castell 1998).

\section{Conclusions}

Early detection of pregnancy and determination of the fetal numbers have economical benefits to sheep producers. The method used for pregnancy diagnosis should be simple, accurate, rapid, inexpensive, practical and safe for both operators and animals. Accurate pregnancy diagnosis can be achieved by progesterone and oPAG or oPSPB assays, however, their accuracy for differentiating single and multiple fetuses would not be regarded as sufficiently high to be of practical value and they are expensive. Rectal abdominal palpation is a simple, cheap and quick method, however its accuracy for determining multiple pregnancies is low and it may cause abortion or rectal perforation. Doppler technique requires great skill to achieve high accuracy for prediction of fetal numbers. Radiography and transabdominal B-mode ultrasonography accurately diagnose both pregnancy and fetal numbers, but the second technique is cheaper than the first one and has the advantages of being safe and able to detect the fetal viability. The optimum time for using transabdominal or transrectal ultrasonography in sheep ranges from 25 to 100 days of gestation. 


\section{Diagnostika březosti u ovcí: přehled nejdůležitějších praktických metod}

Pro stanovení březosti u ovcí se využívají různé praktické metody. Březost i počet plodů lze spolehlivě radiologicky vyšetřit po 70 dnu březosti. Rektální abdominální technika detekuje březost s přesností 66-100\% od 49. do 109. dne březosti, s nízkou přesností stanovení(17-57\%) počtu plodů. Progesteronové metody jsou vysoce citlivé (88-100\%) s nízkou specifitou (60$72 \%$ ), od 16. do 18. dne. Stanovení estron sulfátu přesně detekuje březí ovce od 30. do 35 . dne březosti. Metoda bovinního specifického proteinu březosti B (PSPB) s přesností (100\%) detekuje březost již od 26. dne. Spolehlivost těchto metod - progesteronové, estron sulfátové a PSPB metody technikou "A-mode" a Dopplerovou lze březost přesně detekovat v druhé polovině. Počet plodů nemůže být stanoven technikou A mode, zatímco za použití Dopplerovy je třeba získat další zkušenosti abychom mohli dosáhnout vyšší přesnosti. Transrektální ultrasonografický postup "B-mode" identifikuje počet embryí již 13. den po zabřeznutí, ale citlivost techniky pro březost je velmi nízká (12\%), menší než 25 . den po zabřeznutí. U transabdominální B-mode ultrasonografie bylo dosaženo vysoké spolehlivosti pro diagnostiku březosti (94-100\%) a stanovení počtu plodů (92-99\%) od 29. do 106. dne. Tato metoda diagnostiky březosti a stanovení počtu plodů u ovcí je v současné době nejpřesnější a praktická.

\section{References}

AIUMLAMAI, S., FREDRIKSSON, G., NILSFORS, L. 1992: Real-time ultrasonography for determining the gestational age of ewes. Vet. Rec. 131: 560-562

AMEZCUA-MORENO, M. D. R. 1988: Pregnancy diagnosis in ewes by means of the determination of blood progesterone concentration on Day18 after insemination using enzyme immunoassay. Vet. Mexico 19: 386 (Abstract)

BORJESSON, D. L., BOYCE, W. M., GARDNER, I. A., DEFORGE, J., LASLEY, B. 1996: Pregnancy detection in Bighorn sheep (Ovis canadensis) using a fecal-based enzyme immunoassay. J. Wildl. Dis. 32: 67-74

BRETZLAFF, K., EDWARDS, J., FORREST, D., NUTI, L. 1993: Ultrasonographic determination of pregnancy in small ruminants. Vet. Med. 88: 12-24

BUCKRELL, B. C., BONNETT, B. N., JOHNSON, W. H. 1986: The use of real-time ultrasound rectally for early pregnancy diagnosis in sheep. Theriogenology 25: 665-673

BUTLER, J. E., HAMILTON, W. C., SASSER, R. G., RUDER, C. A., HASS, G. M., WILLIAMS, R. R. 1982: Detection and partial characterization of two bovine pregnancy-specific proteins. Biol. Reprod. 26: 925-933

CHAN, J. S. D., ROBERTSON, H. A., FRIESEN, H. G. 1978: Maternal and fetal concentration of ovine placental lactogen measured by RIA. Endocrin. 102: 1606-1613

CHAUHAN, F. S., SANDABE, U. K., OYEDIPE, E. O. 1991: Predicting number of fetus(es) in small ruminants. Indian Vet. J. 68: 751-754

CHAUHAN, F. S., WAZIRI, M. A. 1991: Evaluation of rectal-abdominal palpation technique and hormonal diagnosis of pregnancy in small ruminants. Indian J. Anim. Reprod. 12: 63-67

COUBROUGH, C. A., CASTELL, M. C. 1998: Fetal sex determination by ultrasonically locating the genital tubercle in ewes. Theriogenology 50: 263-267

DAVEY, C. G. 1986: An evaluation of pregnancy testing in sheep using a real-time ultrasound scanner. Aust. Vet. J. 63: $347-348$

DEAS, D.W. 1977: Pregnancy diagnosis in the ewe by an ultrasonic rectal probe. Vet. Rec. 101: 113-115

DOIZE, F., VAILLANCOURT, D., CARABIN, H., BELANGER, D. 1997: Determination of gestational age in sheep and goats using transrectal ultrasonographic measurement of placentomes. Theriogenology 48: 449-460

ECKBLAD, W. P., SASSER, R. G., RUDER C. A., PANLASIGUI, P., KUCZYNSKI, T. 1985: Localization of pregnancy-specific protein B (PSPB) in bovine placental cells using glucose oxidase-anti-glucose oxidase immunohistochemical stain. J. Anim. Sci. 61 (Suppl.): 149-150

FOLCH, J., BENITEZ, W., ALABART, J. L., BECKERS, J.F. 1993: Determination de la concentracion plasmatica de PAG (pregnancy- assosciated glycoprotein) en cabras Blanca Celtibérica y su utilizacion como diagnostico de gestacion. ITEA 12: 364-366 (in Spanish).

FORD, E. J. H., CLARK, J. W., GALLUP, A. L. 1963: The detection of fetal numbers in sheep by means of Xrays. Vet. Rec. 75: 958-960

FORD, E. J. H. 1983: Pregnancy toxemia. In: MARTIN, W. B.: Diseases of sheep. Blackwell Scientific Publications, London, pp. 147-151

FOWLER, D. G., WILKINS, J. F. 1984: Diagnosis of pregnancy and number of the fetuses in sheep by real-time ultrasonic imaging. 1. Effect of number of fetuses, stage of gestation, operator and breed of ewe on accuracy of diagnosis. Livest. Prod. Sci. 11: 437-450 
FUKUI, Y., KIMURA, T., ONO, H. 1984: Multiple pregnancy diagnosis in sheep using an ultrasonic Doppler method. Vet. Rec. 114: 145

FUKUI, Y., KOBAYASHI, M., TSUBAKI, M., TETSUKA, K., SHIMODA, K., ONO, H. 1986: Comparison of two ultrasonic methods for multiple pregnancy diagnosis in sheep and indicators of multiple pregnant ewes in the blood. Anim. Reprod. Sci. 11: 25-33

GAJEWSKI, Z., BECKERS, J. F., MELO DE SOUSA, N., THUN, R., SULON, J., FAUNDEZ 1999: Determination of pregnancy associated glycoprotein concentrations in sheep: A retrospective study. Advances in Cell Biology 26 (suppl. 12): 89-96 (in Polish)

GARCIA, A., NEARY, M. K., KELLY, G. R., PIERSON, R. A.1993: Accuracy of ultrasonography in early pregnancy diagnosis in the ewe. Theriogenology 39: 847-861

GEARHART, M. A., WINGFIELD, W. E., KNIGHT, A. P., SMITH, J. A., DARGATZ, D. A., BOON, J. A., STOKES C.A. 1988: Real-time ultrasonography for determining pregnancy status and viable fetal numbers in ewes. Theriogenology 30: 323-337

GONZALEZ, B. A., SANTIAGO, M. J., LOPEZ, S. A. 1998: Estimation of fetal development in Manchega dairy ewes by transrectal ultrasonographic measurements. Small Rumin. Res. 27: 243-250

GONZALEZ, F. SULON, J. GARBAYO, J. M., BATISTA, M., CABRERA, F., CALERO, P., GRACIA, A., BECKERS, J. F. 1999: Early pregnancy diagnosis in goats by determination of pregnancy-associated glycoprotein concentrations in plasma samples. Theriogenology 52: 717-725

GRACE, N. D., BEACH, A. D., QUINLIVAN, T. D., WARD, B. 1989: Multiple pregnancy diagnosis of using real time ultrasonic body scanner and video-fluoroscopy systems. Proc. N. Z. Soc. Anim. Prod. 49: 107-111

GVOZDIC, D., IVKOV, V. 1994: Early pregnancy diagnosis in ewes. Acta Vet. (Beograd) 44: 215-219.

HAIBEL, G. K., PERKINS, N. R. 1989: Real-time ultrasonic biparietal diameter of second trimester Suffolk and Finn sheep fetuses and prediction of gestational age. Theriogenology 32: 863-869

HULET, C. V. 1972: A rectal-abdominal palpation technique for diagnosing pregnancy in the ewe. J. Anim. Sci. 35: $814-818$

HULET, C. V. 1973: Determining fetal numbers in pregnant ewes. J. Anim. Sci. 36: 325-330

ILLERA, J. C., GRACIA, O., SILVAN, G., ILLERA, M. J., MUNRO, C. J., ILLERA, M. 2000. Assessment of fetal number and fetal viability throughout pregnancy in Manchega ewe. 14th Inter. Cong. Anim. Reprod., Stockholm, 2:181

ISHWAR, A. K. 1995: Pregnancy diagnosis in sheep and goat: A review. Small Rumin. Res. 17: 37-44

KALKAN C., CETIN, H., KAYGUSUZOGLU, E., YILMAZ, B., CIFTCI, M., YILDIZ H., YILDIZ, A., DEVECI, H., APAYDIN A. M., OCAL, H. 1996: An investigation on plasma progesterone levels during pregnancy and parturition in the Ivesi sheep. Acta Vet. Hung. 44: 335-340.

KELLY, R. W., NEWNHAM, J. P., JOHNSON, T., SPEIJERS, E. J. 1987: An ultrasound technique to measure placental growth in ewes. Aust. J. Agric. Res. 38: 757-764

KELLY, R. W., NEWNHAM, J. P. 1989: Estimation of gestational age in Merino ewes by ultrasound measurement of fetal head size. Aust. J. Agri. Res. 40: 1293-1299

KUTTY, C. I., SUDARSANAN, V. 1996: Bimanual examination of reproductive organs of nanny goats. Proc. 8th Kerala Sci. Cong. 113-114

KUTTY, C. I. 1999: Gynecological examination and pregnancy diagnosis in small ruminants using bimanual palpation technique: A review. Theriogenology 51: 1555-1564

LINDAHL, I. L. 1971: Pregnancy diagnosis in the ewe by intrarectal Doppler. J. Anim. Sci. 32: 922-925

LOGUE, N. D., HALL, J. T., MCROBERTS, S., WATERHOUSE, H. 1987: Real-time ultrasonic scanning in sheep: The results of first year of its application on farms in South-west Scotland. Vet. Rec. 121: 146-149

MADEL, A. J. 1983: Detection of pregnancy in ewe lambs by A-mode ultrasound. Vet. Rec. 112:11-12

McPHEE, I. M., TIBERGHIEN, M. P. 1987: Assessment of pregnancy in sheep by analysis of plasma progesterone using an amplified enzyme immunoassay technique. Vet. Rec. 121: 63-65

MEREDITH, M. J., MADANI, M. O. K. 1980: The detection of pregnancy in sheep by A-mode ultrasound. Br. Vet. J. 136: 325-330

RANILLA, M. J., SULON, J., CARRO, M. D., MANTECON, A. R., BECKERS, J. F. 1994: Plasmatic profiles of pregnancy-associated glycoprotein and progesterone levels during gestation in Churra and Merino sheep. Theriogenology 42: 537-545

RANILLA, M. J., SULON, J., MANTECON, A. R., BECKERS, J. F., CARRO, A. D. 1997: Plasma pregnancyassociated glycoprotein and progesterone concentrations in pregnant Assaf ewes carrying single and twin lambs. Small Rumin. Res. 24: 125-131

ROBERTSON, H. A., CHAN, J. S. D., RIESEN, H. G. 1980: The use of a pregnancy-specific antigen, chorionic somatomammotrohin, as an indicator of pregnancy in sheep. J. Reprod. Fert. 58: 279-281

RUDER, C. A., STELLFLUG, J. N., DAHMEN, J. J., SASSER, R. G. 1988: Detection of pregnancy in sheep by radioimmunoassay of sera for pregnancy-specific protein B. Theriogenology 29: 905-912

RUSSEL, A. J. F., GODDARD, P. J. 1995: Small ruminant reproductive ultrasonography. In: GODDARD, P. G.:Veterinary Ultrasonography. CAB International, Wallingford, Oxon OX108DE, UK, pp. 257-274

SANDABE, U. K., CHAUHAN, F. S., CHAUDHRI, S. U. R., WIZIRI, M. A. 1994: Studies on predicting number of foetus(es) in small ruminants. Pakistan Vet. J. 14: 97-100 
SCHNEIDER, F. A., HALLFORD, D. M. 1996: Use of a rapid progesterone radioimmunoassay to predict pregnancy and fetal numbers in ewes. Sheep and Goat Res. J. 12: 33-38

SCHRICK, F. N., INSKEEP, E. K. 1993: Determination of early pregnancy in ewes utilizing transrectal ultrasonography. Theriogenology 40: 295-306

SERGEEV, L., KLEEMANN, D. O., WALKER, S. K., SMITH, D. H., GROSSER, T. I., MANN, T., SEAMARK, R. F. 1990: Real-time ultrasound imaging for predicting ovine fetal age. Theriogenology 34: 593-601

SUSMEL, P., PIASENTIER, E. 1992: Assessment of pregnancy in Bergamasca ewes by analysis of plasma progesterone. Small Rumin. Res. 8: 325-332

SZENCI, O., BECKERS, J. F, HUMBLOT, P., SULON, J., SASSER, G., TAVERNE, M. A. M.,VARGA, J., BALTUSEN, R., SCHEKK, GY. 1998: Comparison of ultrasonography, bovine pregnancy-specific protein B, and bovine pregnancy-associated glycoprotein 1 tests for pregnancy detection in dairy cows. Theriogenology 50: 77-88

TAVERNE, M. A. M., LAVOIR, M. C., VAN OORD, R., VAN DER WEYDEN, G. C. 1985: Accuracy of pregnancy diagnosis and prediction of fetal numbers in sheep with linear-array real- time ultrasound scanning. The Vet. Quart. 7: 256-263

TRAPP, M. J., SLYTER, A. L. 1983: Pregnancy diagnosis in the ewe. J. Anim. Sci. 57: 1-5

TSANG, C. P. W. 1978: Plasma levels of estrone sulphate, free estrogens and progesterone in the pregnant ewe throughout gestation. Theriogenology 10: 97-110

TURNER, C. B., HINDSON, J. C. 1975: An assessment of a method of manual pregnancy diagnosis in the ewe. Vet. Rec. 96: 56-58

TYRRELL, R.N., PLANT, J. W. 1979: Rectal damage in ewes following pregnancy diagnosis by rectal-abdominal palpation. J. Anim. Sci. 48: 348-350

VECCHIO, R. P. D., SUTHERLAND, W. D., SASSER, R. G. 1995: Effect of pregnancy-specific protein B on luteal cell progesterone, prostaglandin, and oxytocin production during two stages of the bovine estrus cycle. J. Anim. Sci. 73: 2662-2668

WALlACE, J. M., AITKEN, R. P., CHEYNE, M. A., HUMBLOT P. 1997: Pregnancy-specific protein B and progesterone concentrations in relation to nutritional regimen, placental mass and pregnancy outcome in growing adolescent ewes carrying singleton fetuses. J. Reprod. Fert. 109: 53-58

WANI, N. A., WANI, G. M., MUFTI, A. M., KHAN, M. Z. 1998: Ultrasonic pregnancy diagnosis in gaddi goats. Small Rumin. Res. 29: 239-240

WATT, B. R., ANDRESON, G. A., CAMPELL, I. P. 1984: A Comparison of six methods used for detecting pregnancy in sheep. Aust. Vet. J. 61: 377-382

WEST, D. M. 1986: Pregnancy diagnosis in the ewe. In: MORROW, D. A.: Current Therapy in Theriogenology. W. B. SAUNDERS, Philadelphia pp. 850-852

WHITE, I. R., RUSSEL, A. J. F., FOWLER, D. G. 1984: Real-time ultrasonic scanning in the diagnosis of pregnancy and the determination of fetal numbers in sheep. Vet. Rec. 115: 140-143

WILLARD, J. M., RUDER, C. A., SASSER, R. G., STELLFLUG, J., 1987: Ovine pregnancy-specific protein B concentration in the sera of early pregnant and peripartum ewes. J. Anim. Sci. 65 (suppl.): 514

WILLARD, J. M., WHITE, D. R., WESSON, C. A. R., STELlFLUG, J., SASSER, R. G. 1995: Detection of fetal twins in sheep using radioimmunoassay for pregnancy-specific protein B. J. Anim. Sci. 73: 960-966

WORSFOLD, A. I., CHAMINGS, R. J., BOOTH, J. M. 1986: Measurement of estrone sulphate in sheep plasma as a possible indicator of pregnancy and the number of viable fetuses present. Br. Vet. J. 142: 195-197

XIE, S., LOW, B. G., NAGEL, R. G., KRAMER, K. K, ANTHONY, R. V., ZOLI, A. P., BECKERS, J. F., ROBERTS, R. M. 1991: Identification of the major pregnancy specific antigens of cattle and sheep as inactive members of aspartic proteinase family. Proc. Nat. Acad. Sci. (USA) 88: 10247-10251

XIE, S., GREEN, J., BANGA, B., BECKERS, J. F., VALDEZ, K. E., HAKAMI, L. ROBERTS, R. M. 1997: Multiple pregnancy-associated glycoproteins are secreted by Day 100 ovine placental tissue. Biol. Reprod. 57: 1384-1393

ZARKAWI, M. 1997: Monitoring the reproductive performance in Awassi ewes using progesterone radioimmunoassay. Small Rumin. Res. 26: 291-294

ZARKAWI, M., AL-MERSETANI, M. R., WARDEH, M. F. 1999: Induction of synchronized estrus and early pregnancy diagnosis in Syrian Awassi ewes outside the breeding season. Small Rumin. Res. 33: 99-102

ZOLI, A. P., BECKERS, J. F., ECTORS, F. 1995: Isolation and partial characterization of a pregnancy-associated glycoprotein in the ewe Ann. Méd.Vét., 139:177-184. (in French)

ZOLI, A. P., GUILBAULT, L. A., DELAHAUT, P., ORTIZ,W. B., BECKERS, J. F. 1992: Radioimmunoassay of a bovine pregnancy-associated glycoprotein in serum: Its application for pregnancy diagnosis. Biol. Reprod. 46:83-92 